Article

\title{
Vulnerability of the Landscape as a Tool for Determining a Suitable Model of Tourism Development
}

\author{
Monika Vyskupová ${ }^{1}$, Zdena Krnáčová $^{2, *}$ and Katarína Pavličková ${ }^{3}$ \\ 1 Department of Environment, Reming Consult Inc. Trnavska Cesta 27, 83104 Bratislava, Slovakia; \\ monikavyskupova@gmail.com \\ 2 Institute of Landscape Ecology, Slovak Academy of Sciences, Stefanikova 3, \\ P.O. Box 254, 81499 Bratislava, Slovakia \\ 3 Department of Environmental Ecology and Landscape Management, Faculty of Natural Sciences, \\ Comenius University in Bratislava, Ilkovicova 6, Mlynska Dolina, 84215 Bratislava, Slovakia; \\ pavlickova60@gmail.com \\ * Correspondence: zdena.krnacova@savba.sk
}

Citation: Vyskupová, M.;

Krnáčová, Z.; Pavličková, K.

Vulnerability of the Landscape as a Tool for Determining a Suitable Model of Tourism Development. Sustainability 2021, 13, 5622.

https://doi.org/10.3390/su13105622

Academic Editor: Ivo Machar

Received: 11 March 2021

Accepted: 13 May 2021

Published: 18 May 2021

Publisher's Note: MDPI stays neutral with regard to jurisdictional claims in published maps and institutional affiliations.

Copyright: (c) 2021 by the authors. Licensee MDPI, Basel, Switzerland. This article is an open access article distributed under the terms and conditions of the Creative Commons Attribution (CC BY) license (https:// creativecommons.org/licenses/by/ $4.0 /)$.

\begin{abstract}
Tourism is known as a developing human activity with major impacts on the local landscape as it produces significant anthropogenic pressure. In recent years, due to globalization and the growing economic power of the population of developed world, it has become one of the most important industries and has grown globally. Along with its development, its impacts on the environment are also growing in direct proportion. Therefore, new tourism models are being created which focus on the reduction in their adverse impacts. To design a proper model of tourism development that is sustainable and environmentally friendly, a complex knowledge of the local landscape is necessary. This paper presents a method for examining the actual state of the landscape and its thresholds by assessing its vulnerability to external impacts. The method is based on the qualitative and quantitative evaluation of landscape components perceived as primary receptors of the effects of anthropogenic activities. A comprehensive database on the landscape enables a transparent and complex evaluation of its current state and potential use. Moreover, it enables us to set its vulnerability, which represents the threshold value for suggesting the appropriate development activities, taking into account the preservation of its required quality for sustaining the points of interest for future tourists. The proposed method can help to determine the sustainable land use of the area and thus better design a model of tourism that is sustainable.
\end{abstract}

Keywords: landscape vulnerability; landscape receptors; landscape vulnerability analysis (LVA); impact; sustainable tourism; landscape ecological planning; limits of environmental development

\section{Introduction}

Landscape represents the primary space for human activities as it provides basic material assets for supporting residential, productive, and recreational activities [1]. It is a complex, dynamically changing system involving different base components (various abiotic and biotic systems) that do not exist side by side in isolation, but do interact with each other, change during time, acquire new characteristics and are organized together into a landscape structure. The landscape structure consists of its primary (basic structural elements), secondary (current land use) and tertiary elements (socioeconomic phenomena), associated in mutual horizontal and vertical connections [2]. All of these elements together represent the utility features that create the potential of the landscape for its economic use.

As the landscape is the basic environment of human realization, it is also the material basis for tourism activities which consist of temporary travelling to and staying in places outside the usual man's environment [3]. Their realization depends on the presence of an object of interest-on the local natural and anthropogenic sources and on the social and technical conditions of particular locality. In general, the relationship between tourism 
and landscape is bidirectional: landscape parameters present the point of interests for potential tourism development and simultaneously, tourism enters the landscape that is therefore affected [4]. This relationship is hence not consistent in time or space, it may vary according to the current intensity of exploitation and the level of caused impacts. The most spread commercial tourism generates a large volume of tourists and associated recreational and leisure activities, increases consumption, generates long-term consequences and puts strong pressure on the affected landscape, especially on the landscape whose resources are sensitive or already rare [5]. Therefore, different tourism models are being formed in recent years, which focus on the reduction in their adverse impacts to eliminate the negative physical effects and to maintain sufficient quality of the affected landscape for its future development. This can be referred to as the concept of so-called sustainable tourism [6].

To design the proper model of tourism development that is sustainable and environmentally friendly, the complex knowledge of the local landscape as the primary source is necessary. Moreover, as the development of tourism brings anthropogenic activities to the area and comes together with spatial, economic, cultural, and environmental costs [7] for considering the sustainable model of tourism, it is necessary to know the local assets and specifics together with the level of their resistance or resilience.

Landscape ecology research deals with these questions; its priority interest is the effort to find specific approaches to guide the uncontrolled socio-economic development of the landscape, i.e., to enforce sustainable landscape planning $[2,8,9]$. Therefore, it has suggested various concepts for the landscape research and evaluations that differ in the purpose of their use and/or in the way of their processing [10].

In order to understand the landscape in terms of its usage and development, the concept of landscape vulnerability has been created. This phenomenon expresses the susceptibility of the landscape to negative aberration caused by anthropogenic and/or natural factors [11]. It is one of the principal functional landscape attributes, the synthetic properties of the landscape, resulting in the interaction of the status and properties of its partial components [10]. Recognition of landscape vulnerability helps to determine the limits of a certain area, to which it can be used without inducing negative changes [12]. It takes into account not only changes in the system after exposure to possible perturbances and stressors, but also its sensitivity and resistance to a given adverse effect [13]. With the correct determination of the vulnerability of the affected area, it is thus possible to assess the effect of human impacts on the area more accurately. The analysis of landscape vulnerability is thus a suitable tool for determining the optimal land use, as it is a relevant source of information about the research area and enables the coordination of individual interests there [11].

The presented paper outlines a specific method for examining the actual state of the landscape and its certain thresholds by assessing its vulnerability, which determines the sustainable and environmentally friendly model of tourism. The suggested landscape vulnerability method consists of a qualitative evaluation of specific landscape receptors, their quantitative scoring, determining the degree of their vulnerability, and interpreting the results for a particular purpose.

\section{Determining Landscape Vulnerability}

Vulnerability analysis has proven to be the proper method that provides relevant information about landscape with a range of values enabling the possibility of the coordination of individual interests [13]. Landscape vulnerability is assessed mainly on the basis of identification of driving forces (development trends), quantification of potential impacts on landscape and spatial representation of possible changes (conversion or intensification of landscape elements, etc.). The interests of a society are the reference values for comparing the identified data. The landscape vulnerability analysis follows the structure of a deduction-based approach, where the concepts are built according to a theoretical base [14].

To be accurate and actual, the vulnerability analysis requires the broad input data of the evaluated landscape. To conduct it precisely, the starting point should be the comprehensive 
landscape analysis. Since landscape is the complex heterogeneous system, the best way to explore it is by precise analysis of its partial components: abiotic, biotic, and socio-economic landscape structure elements. All of these basic landscape elements can be marked as landscape receptors, because they are the main recipients of external impacts-in this specific case, the impacts of the tourism activities. The analysis of landscape receptors should summarize all of the available information of their current condition, their spatial occurrence, and the intensity of their contamination or degradation. An important issue here is also recency, relevance, and representativeness of data $[15,16]$. In practice, the major issue is their availability.

As the individual landscape receptors vary considerably from one another and include various natural and socioeconomic elements and their mutual relations, it is easier to assess their vulnerability using specific and appropriately selected criteria [17]. These should be chosen by individually taking into account the nature and specifics of each receptor and their mutual relations. Simultaneously, the requirement of their future comparison should be considered.

To date, several methodological techniques have been proposed to assess landscape vulnerability. The diversity of approaches studying and assessing landscape vulnerability is necessary in order to address the full complexity of this concept and to ensure that the approaches are in large part complementary [18].

Specifically, the use of indicator evaluation and the quantifying and ranking of the resulting values has been tried $[17,19,20]$, the sensitivity assessment of selected variables of concerns in comparison to the frequency and magnitude of identified stressors has been initiated [21], and the spatial component analysis with geographic information systems has been considered [22]. The specific vulnerability assessment of social-environmental systems has also been developed [18]. Even in the conditions of Slovakia, an effort was initiated to create a procedure for assessing landscape vulnerability [23]. This proposal assesses the vulnerability of landscape components, quality of life, and also the ecological significance of the landscape. The final landscape vulnerability is determined by the synthesis of the obtained data using the method of maps overlying.

As seen above, all of these techniques are mostly based on the proper combination of existing methods led by expert judgment, while the research object is too comprehensive and requires a specific approach [24]. All of the suggested methods try to assess the landscape through specific criteria (indicators, variables) that are quantified and ranked according to a defined scope to better reflect their importance and for easier mutual comparison. Finally, the results are compared to specific stressors (impacts). Sometimes, specific formulas or indexes have been also developed [20,22].

Even different methods for the landscape vulnerability analysis have been developed, they are constantly hard to follow, data intensive, time-consuming, and there still remains a certain need to better reflect the inner landscape relations and the socioeconomic demands [24]. Moreover, the particular requirements usually have particular needs; therefore, different methods are being suggested for different use. In addition, tourism development has its specifics and the method presented below tries to fully reflect them.

\section{Methodical Section}

The presented methodological procedure for landscape vulnerability analysis (LVA) follows the basic landscape ecological principles, it respects the diversity of the variables, their mutual connectivity, their adaptive capacity, and it takes their systematic functioning into account [10]. The method lies on the basis of the multicriteria analysis, on the principles of systematism, criteria identification, multi-level evaluation, and scoring [25,26]. It is based on a proper combination of several existing methodological procedures, namely LANDEP [27], landscape carrying capacity assessment [28], landscape diagnosis [29], landscape vulnerability assessment [14], multicriteria analysis (MCA) [26] and vulnerability assessment $[17,30]$. In general, the procedure is based on the principles of landscape 
ecological planning [27] as it tries to suggest the (ecologically) optimal use of the landscape with the proposal of the most appropriate distribution of social activities to maintain its suitable quality. The analytical part of the LVA method consists of the characterization of specific landscape receptors, based on the reassessment and homogenization of specialized data $[27,28]$ and their quantitative evaluation by specific criteria and their scoring $[14,20,31]$. The synthetic part consists of the mutual consideration of the information about landscape receptors and their systematic functions [29,32]. Finally, interpretations of the results suggest the current limits or thresholds that lead to the precise proposal for future local development $[14,27]$ together with specification of the uncertainties.

Specifically, the LVA method is based on the analysis of vulnerability of individual landscape components that represent the basic receptors of the effects of human activities [33]. With regard to the possibility of using the method in the practical application of environmental management, the effort was to simplify the individual process steps as much as possible:

1. Determination of the basic set of landscape receptors.

2. Determination of vulnerability assessment criteria.

3. Quantitative assessment of vulnerability criteria.

4. Determination of the degree of receptor vulnerability.

5. Expression of the reliability of the evaluation.

\subsection{Determination of the Basic Set of Landscape Receptors}

Landscape ecological assessment of the landscape as a unit is based on the knowledge of their components, so-called landscape receptors. They cover all the basic spheres of the landscape, and include geophysical and biophysical receptors, landscape receptors, and socioeconomic receptors:

- Geophysical and biophysical receptors represent the basic abiotic and biotic characteristics of the landscape, including the receptors relief, rock environment, soil, air and local climate, water, and biota (flora, fauna, biotopes).

- Landscape receptors include aggregate parts of the landscape primarily perceived as receptors of change, namely the landscape structure, the landscape image, and the ecological stability of the landscape.

- Socio-economic receptors represent the requirements of society in a given area. They include the society's activities in the area, such as settlements, cultural and historical values, protected areas, tourism and recreation, agriculture, industry and technical, and transport infrastructure.

In pursuance of the previous experience from the theoretical and applied landscape ecological research, a basic set of landscape receptors was created, on the basis of which a relevant assessment of landscape vulnerability can be performed (Table 1). However, as the condition of the landscape is influenced by several factors, especially its character (type), physical-geographical and regional differences, degree of anthropogenic use, degree of damage, etc., there is no universal set of receptors that is optimal for each assessment. The choice of receptors is usually carried out on the basis of knowledge of the evaluated area and specific requirements for the assessment itself. 
Table 1. Basic set of receptors and their vulnerability assessment criteria.

\begin{tabular}{cc}
\hline Receptor & Vulnerability Assessment Criteria \\
\hline Relief & Vertical division of the territory \\
& Morphological-morphometric types of relief \\
Altitude & The slope of the territory \\
\hline Rock environment & Type of quaternary sediments \\
& Subsoil thickness \\
& Engineering-geological properties \\
& Occurrence of seismic-tectonic phenomena \\
Occurrence of geodynamic phenomena & Presence of mineral resources \\
Contamination of the rock environment
\end{tabular}

\begin{tabular}{|c|c|}
\hline Water & $\begin{array}{c}\text { Occurrence of water management protected areas } \\
\text { Surface water flow } \\
\text { Surface water quality } \\
\text { Groundwater level } \\
\text { Groundwater quality } \\
\text { Occurrence of springs }\end{array}$ \\
\hline Biota & $\begin{array}{c}\text { Type of vegetation cover } \\
\text { Shape and size of vegetation areas } \\
\text { Forest health } \\
\text { Species occurrence } \\
\text { Origin of species } \\
\text { Significant migration corridors }\end{array}$ \\
\hline Biotopes & $\begin{array}{c}\text { Biotope type } \\
\text { Biotope condition } \\
\text { Spatial representation of biotope }\end{array}$ \\
\hline \multicolumn{2}{|c|}{ Landscape receptors } \\
\hline Landscape structure & $\begin{array}{l}\text { Types of landscape elements } \\
\text { Land use } \\
\text { Landscape mosaic }\end{array}$ \\
\hline Landscape image & $\begin{array}{l}\text { Landscape image } \\
\text { Architectural trends }\end{array}$ \\
\hline Ecological stability of the landscape & $\begin{array}{l}\text { Current state of landscape elements } \\
\text { Ecological significance of landscape elements }\end{array}$ \\
\hline \multicolumn{2}{|c|}{ Socioeconomic receptors } \\
\hline Settlements & $\begin{array}{l}\text { Population density } \\
\text { Degree of urbanization } \\
\text { Development trends }\end{array}$ \\
\hline Cultural and historical values & $\begin{array}{l}\text { Representation and status of cultural monuments } \\
\text { Local traditions and customs }\end{array}$ \\
\hline Protected areas & $\begin{array}{c}\text { Areas protected by law } \\
\text { NATURA } 2000 \text { sites } \\
\text { Biotopes of European and national importance } \\
\text { Territorial system of ecological stability }\end{array}$ \\
\hline
\end{tabular}


Table 1. Cont.

\begin{tabular}{cc}
\hline Receptor & Vulnerability Assessment Criteria \\
\hline Geophysical and Biophysical Receptors \\
Tourism and recreation & $\begin{array}{c}\text { Natural attractions of the area } \\
\text { Cultural and historical attractions of the area } \\
\text { Tourism facilities }\end{array}$ \\
\hline Agriculture & Representation of arable land \\
Thdustry & $\begin{array}{c}\text { Industrial base structure } \\
\text { Development trends }\end{array}$ \\
\hline Technical infrastructure & Elements of technical infrastructure \\
Network connection
\end{tabular}

\subsection{Determination of Vulnerability Assessment Criteria}

For each landscape receptor, the specific evaluation criteria of its vulnerability are suggested in the second step of the LVA method (Table 1). These criteria interpret the basic characteristic and specifics of the receptors that are crucial for its current or future use. Based on these, it is possible to characterize the receptor in detail, to evaluate its present status and also its sensitivity to possible fluctuations caused by external influences. The selected criteria serve as a tool for comparing essential information, on the basis of which it is finally possible to provide a representative picture of the vulnerability of the examined receptor. When selected appropriately, they enable systematic analysis, which contributes to a higher objectification of the results. Moreover, in cooperation with experts from various fields of landscape ecological research and the complex picture of vertical and horizontal relations between them, its holistic function can be better understood.

\subsection{Quantitative Assessment of Vulnerability Criteria}

The goal of this step is to identify the level of the vulnerability of each landscape receptor that subsequently enables us to determine the overall vulnerability of the landscape. This is conducted using the vulnerability criteria-for each criterion, the values of two basic indicators determining its vulnerability are set: the degree of its sensitivity and the level of its significance:

- The degree of sensitivity of the criterion expresses its sensitivity to the effects of any external interventions; it is a numerical expression of the qualitative evaluation of the obtained characteristics of the criterion for the model area.

- The degree of significance of a criterion expresses the importance of that criterion in comparison to other criteria that together describe the receptor. It reflects the relevance of the criterion in the functioning the receptor as a unit.

The values of these two indicators are assigned to the criteria according to the evaluation scales given in Table 2, on the basis of data obtained from the performed qualitative analysis in the prior step. The numerical expressions better signify the importance of each value and are also preferable for mutual comparisons. 
Table 2. Evaluation scale for indicators of vulnerability criteria.

\begin{tabular}{|c|c|c|c|}
\hline Factor & & & Values \\
\hline \multirow{5}{*}{ Sensitivity } & 1 & very low sensitivity & $\begin{array}{l}\text { The receptor is very insensitive to external } \\
\text { influences. During the action of external influence, } \\
\text { the receptor is almost unaffected, or it is only } \\
\text { minimally affected, and is able to return to its initial } \\
\text { state immediately. }\end{array}$ \\
\hline & 2 & low sensitivity & $\begin{array}{l}\text { The sensitivity of the receptor to external influences } \\
\text { is low, the receptor is able to return to its original } \\
\text { state by its own autoregulatory mechanisms after } \\
\text { the end of the action of disturbance. }\end{array}$ \\
\hline & 3 & medium sensitivity & $\begin{array}{l}\text { The sensitivity of the receptor to disturbances is } \\
\text { moderate, i.e., the receptor is able to return to its } \\
\text { original state at the end of their action, but usually } \\
\text { aid measures are needed. }\end{array}$ \\
\hline & 4 & high sensitivity & $\begin{array}{l}\text { The sensitivity of the receptor to external influences } \\
\text { is high, a strong degradation of its state and } \\
\text { properties is expected. Return of the receptor to its } \\
\text { original state is possible with the input of external } \\
\text { forces, i.e., using an appropriate combination of } \\
\text { measures and technical interventions. }\end{array}$ \\
\hline & 5 & very high sensitivity & $\begin{array}{l}\text { The sensitivity of the receptor to external influences } \\
\text { is high, a strong degradation of its state and } \\
\text { properties is expected. Restoration of the receptor is } \\
\text { possible only with the help of demanding measures } \\
\text { and technical interventions. }\end{array}$ \\
\hline Relevance & $0-100 \%$ & \multicolumn{2}{|c|}{ The sum of the significances of all criteria of a given receptor is $100 \%$. } \\
\hline
\end{tabular}

\subsection{Determining the Degree of Vulnerability}

The overall vulnerability degree of each landscape receptor is obtained by mutual comparison of the partial indicator values of their criterion. This step provides a representative picture of the vulnerability of the investigated receptor, and as it is also done numerically, it is flexible enough for the subsequent evaluation and interpretation of the results. A standard mathematical procedure is used to process the values of indicators: the vulnerability degree of a landscape receptor comes out of the average of sensitivity values of all its criteria considering their significance for its overall vulnerability. The final vulnerability of each receptor is calculated as a standard weighted arithmetic mean $[34,35]$ as presented in Equation (1):

$$
\bar{V}=\frac{1}{n} \sum_{i=1}^{k} S E_{i} S I_{i}
$$

where $\bar{V}$ indicates the degree of receptor vulnerability, $S E$ indicates the sensitivity value, $S I$ is the significance of the criterion and $n$ is the range of the whole set of criteria $(i=1,2, \ldots, k)$. The obtained values of the vulnerability range from 1 (very low vulnerability) to 5 (very high vulnerability), they are based on the determined sensitivity values of the assessment criteria.

\subsection{Degree of Reliability of Evaluation of the Selected Criteria}

The vulnerability evaluation of the landscape receptors outlined in the LVA method is based on their criterion assessment, specifically on averaging the weighted values of the basic indicators of each criterion-its degrees of sensitivity. However, as this variable is not directly measurable and is set by expert judgement, it is determined with a particular degree of uncertainty. Moreover, the variability of the methods used is not reflected, nor their accuracy. To make the assessment more accurate, these deficiencies can be reduced by describing the degree of reliability of the vulnerability assessment for each receptor. Then, the obtained values can better reflect the reality and the resulting degree of uncertainty can help in the verbal formulation of proposals and recommendations con- 
cerning the receptor, or to identify the need for further research and completion of the relevant database.

The degree of reliability can be expressed by a confidence interval. It expresses the level of (un)certainty with which the sensitivity degree of each criterion has been determined. Thus, this indicator also expresses the accuracy of the method used to determine the vulnerability of each receptor.

To estimate the degree of reliability of the assessment, it is necessary to determine the partial confidence intervals for each criterion of vulnerability, i.e., for each determined sensitivity degree of the assessed criterion. The range of values for this step is given in Table 3.

Table 3. Evaluation scale of confidence intervals of receptor assessment criteria.

\begin{tabular}{ll}
\hline \multicolumn{1}{c}{ Factor } & \multicolumn{1}{c}{ Values } \\
\hline 0.1 & $\begin{array}{l}\text { The degree of sensitivity of a criterion is determined by an } \\
\text { expert assessment of an expert in the given scientific field, on } \\
\text { the basis of complete necessary data on the given criterion, or } \\
\text { on the basis of a realized scientific assessment of the } \\
\text { vulnerability of the given criterion, according to a recognized } \\
\text { methodological procedure. }\end{array}$ \\
\cline { 2 - 4 } Confidence Interval & $\begin{array}{l}\text { The degree of sensitivity of a criterion is determined by expert } \\
\text { judgment on the basis of complete necessary data on the given } \\
\text { criterion. }\end{array}$ \\
\hline $0.5 \quad \begin{array}{l}\text { The degree of sensitivity of a criterion is determined by expert } \\
\text { judgment on the basis of obtained available data on the given } \\
\text { criterion. }\end{array}$ \\
\hline $0.7 \quad \begin{array}{l}\text { The degree of sensitivity of a criterion is determined by } \\
\text { estimation on the basis of incomplete data on the given } \\
\text { criterion. }\end{array}$ \\
\hline 1 & $\begin{array}{l}\text { The degree of sensitivity of a criterion is determined by } \\
\text { estimation on the basis of missing data on the given criterion. }\end{array}$ \\
\hline
\end{tabular}

To settle the overall degree of uncertainty for the vulnerability assessment of the receptor, it is not sufficient to just count the confidence intervals obtained to the individual values, as these are not interdependent. It is necessary to also take into account directly the sensitivity values of the criteria of a given receptor, as the more variable these values are, the less certainty there is in determining its overall vulnerability. The resulting confidence interval for assessing receptor vulnerability (Equation (2)) can thus be determined using an appropriate combination of mathematical methods that reflects the variance of the sensitivity values of the criteria, the confidence interval of the set of criteria, and weighting of values [35-37]:

$$
\Delta Z=\sqrt{\left(\frac{\sqrt{\sum_{i=1}^{n} \Delta x_{i}{ }^{2} \cdot f_{i}{ }^{2}}}{\left(\sum_{i=1}^{n} f_{i}\right)^{2}} \cdot n\right)^{2}+\left(\frac{\sqrt{\frac{1}{n-1} \sum_{i=1}^{n}\left(x_{i}-\bar{x}\right)^{2} \cdot f_{i}{ }^{2}}}{\left(\sum_{i=1}^{n} f_{i}\right)^{2}}\right)^{2}}
$$

where $\Delta Z$ is the total confidence interval of the receptor, $x_{i}$ are the sensitivity values of individual criteria, $\Delta x i$ are the confidence intervals of individual criteria, $f_{i}$ expresses the values of significance of individual criteria, $\bar{x}$ presents the weighted average of the sensitivity values of individual criteria, and $n$ expresses the total number of criteria. The resulting values of the confidence intervals reflects the degree of uncertainty of the assessment performed-while the higher the value of the confidence interval, the greater the degree of uncertainty in determining the degree of receptor vulnerability. 


\section{Results}

\subsection{Study Site}

The presented methodological procedure was used to assess the vulnerability of a well-known recreational area in western Slovakia—the locality Železná Studnička, which is part of the capital of the Slovak Republic, Bratislava (Figure 1). The area is located on the southern edge of the Little Carpathians and has a rich tradition in terms of use for tourism. Due to the presence of mineral springs rich in carbonate salts and iron, it became an important spa area of the Hungarian nobility; in the 19th century a spa complex for the treatment of cardiovascular diseases was built here [38]. However, the original use of the site as a spa was terminated due to the extinction of healing mineral springs, because of the disruption of the groundwater regime, due to a large increase in construction activities and modifications to the local watercourse. At present, in addition to the preserved natural values, the location also provides rich opportunities for tourism, recreation, and sports, while it is very accessible from the wider surrounding area.

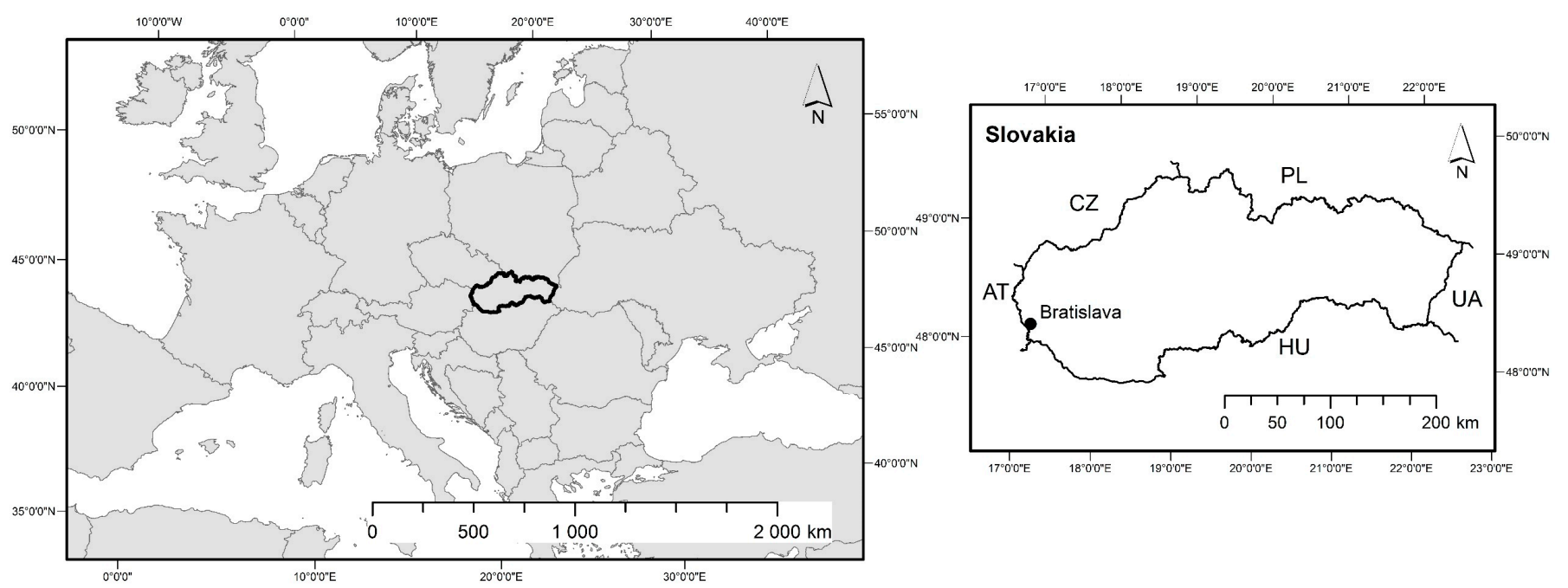

Figure 1. Location of a model area.

From the point of view of tourism, the favorable accessibility of the study site is important. The internal interconnection of the area is also very well secured; the site is interspersed with a rich network of paved and unpaved roads, hiking trails, and cycle paths (cyclists make up approximately 13\% of all visitors to the site [29]), which also connect the Železná studnička area with the capital in the south, adjoining the areas of the Little Carpathians in the north, the neighbouring region of Záhorie in the west, and the Little Carpathian vineyard area in the east.

In terms of use, the Železná studienka site is divided into three functional zones, the intensive recreation zone (A), the recreation zone, nature protection, and forestry $(\mathrm{B})$, and the nature protection and recreation zone (C).

Most of the model area is covered by the forests of the Little Carpathians, categorized as forests of special purpose, suitable for recreation. The stands include mainly oaks, beeches, burrows, and lindens, the forests are managed by the Bratislava Municipal Forests. The Bystrička stream and Vydrica stream, which represents the most important watercourse in the area, flow through the model area. Four water reservoirs were built on it (Figure 2), and there are several wells and smaller springs, as well as several wetlands. Local flora represents Western Carpathians flora, local fauna is represented by species typical for Carpathian forests as well, although the occurrence of species is influenced by human activities. Several rare, threatened, or protected species have been recorded here, together with different species of bats and more than 50 bird species, most of which occur here in the nesting season. 


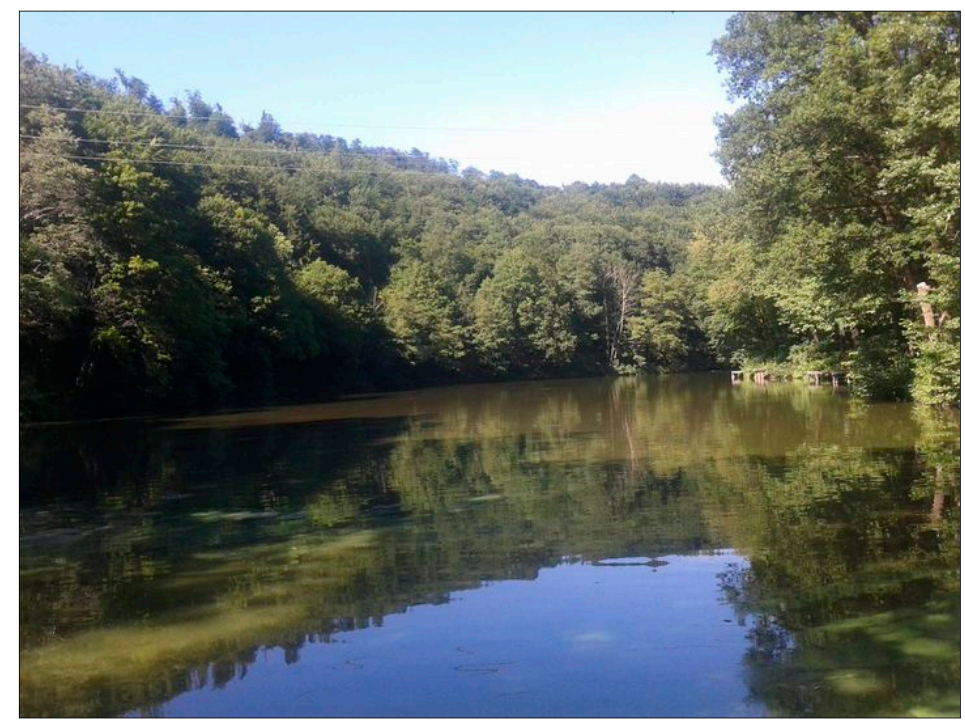

Figure 2. The landscape image in the locality of the Železná studnička is completed by ponds.

The model area is part of the protected landscape area of the Little Carpathians, which was declared for the protection of forest communities with a natural species composition, with communities at the border of the Carpathian and Pannonian bioregions. The Vydrica stream has become part of the European network of Natura 2000 protected areas and is an area of European importance. Vydrica has been declared for the protection of the remains of indigenous forest communities and several species of European importance. At the southern edge of the model area, a protected eastern sycamore tree with a high biological and aesthetic value is registered. There are several original forest habitats and habitats of European importance in the area, especially floodplain willow-poplar and alder forests in the alluvium of Vydrica, beech and fir flowery forests on the slopes, acid-loving beech forests, and linden-maple rubble forests. Due to its functional use and proximity to urban development, protected areas in the model locality are exposed to strong civilization pressure, especially the expansion of Bratislava's urban background, direct intervention due to increasing demands on the representation of recreational and sports elements, and negative impacts associated with high intensity of visitor movement.

The model area is part of the area, which is the most visited recreation and tourist spot for the inhabitants of the capital city, into whose ownership and administration the site passed at the end of the 19th century. The main tourist attractions of the area include not only the natural conditions of the locality, but also the still present historical buildings and opportunities for passive and active recreation, including many recreational and sports activities. As shown by the processed traffic survey carried out in the months of June and July [39], more than 7300 visitors move in the area from 8:00 to 15:00, daily. The main centres of short-term and dynamic recreation are the localities Koliba-Kamzík, Horná Mlynská dolina, and Kačín. In the recreational area Kamzík, several functional zones have been created, including accommodation and food services, the area of Cvičná lúka offers rich possibilities of sports activities in winter and summer, together with soft recreational equipment (buffets, summer houses, fireplaces, etc.). Horná Mlynská dolina is located in the southern part of the model area near the Vydrica river, it is used for spring, summer, and autumn recreation, while recreational use is concentrated mainly in places of built infrastructure (seating, fireplaces, gazebos, playgrounds, cafeterias, etc.), several playgrounds, and different sport areas. Kačín is also a partially equipped locality where one can find seating, fireplaces, and seasonal buffets. The other subjects of importance there are several historical attractions such as military bunkers, the remains of watermills, fishing facilities, etc. and several cultural events, focused mainly on families and children's visitors (e.g., roasting, children's plays, open theatre performances, etc.). 


\subsection{Landscape Vulnerability Analysis of the Model Area}

Knowledge of the properties and current state of the components of the environment of the model area is crucial for the application of the methodological procedure. For this reason, a detailed environmental characteristic of the area was processed. It contained information on geophysical, biophysical, landscape, and socio-economic components of the site, their spatial representation, their use, and their current quality in terms of contamination or degradation. Emphasis was placed on receptors important for tourism, whether on significant natural values or on elements of recreational and sports infrastructure. At the same time, efforts were made to identify activities with direct and indirect effects on the quality of these receptors. The data sources were available data from professional literature, processed studies, databases, and environmental information systems, as well as additional research, including field research of the site.

When examining the vulnerability of the model area, we focused on its southern part, which is most significantly attacked, not only in terms of high intensity recreational use, but also due to its peripheral location, which is in contact with the urbanized part of the capital.

First of all, an inventory of environmental resources was developed consisting of collecting a variety data associated with geophysical, biophysical, landscape, and socioeconomic elements related with recreational use. The study site was explored to establish local nature values and recreational facilities. The landscape structure of the model area was verified by a field survey carried out in the locality in 2017; together a total of 27 different landscape elements were identified (Figure 3). The territory is dominated by forest stands, which make up more than $82 \%$ of its area. The rest of the site is covered by meadows and grasslands (4\%), non-forest woody vegetation, together with stream-side vegetation (3.5\%), water areas $(0.5 \%)$, built-up areas of family, and apartment houses and administration $(3 \%)$, recreation and sport areas $(2 \%)$, and technical components such as military bunkers, quarries, or power lines (1.5\%), and transport infrastructure (3.5\%). Figure 4 presents the area representation of the main elements of the current landscape structure.

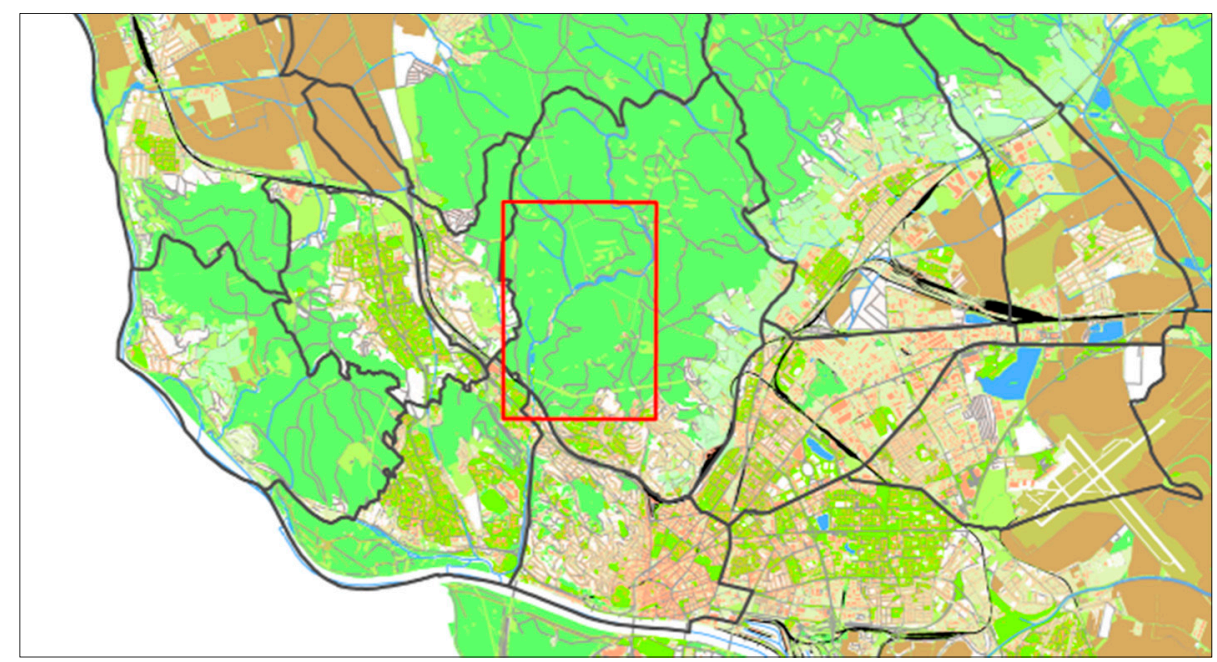

Figure 3. The current landscape structure of the model area in the context of the wider surroundings. 


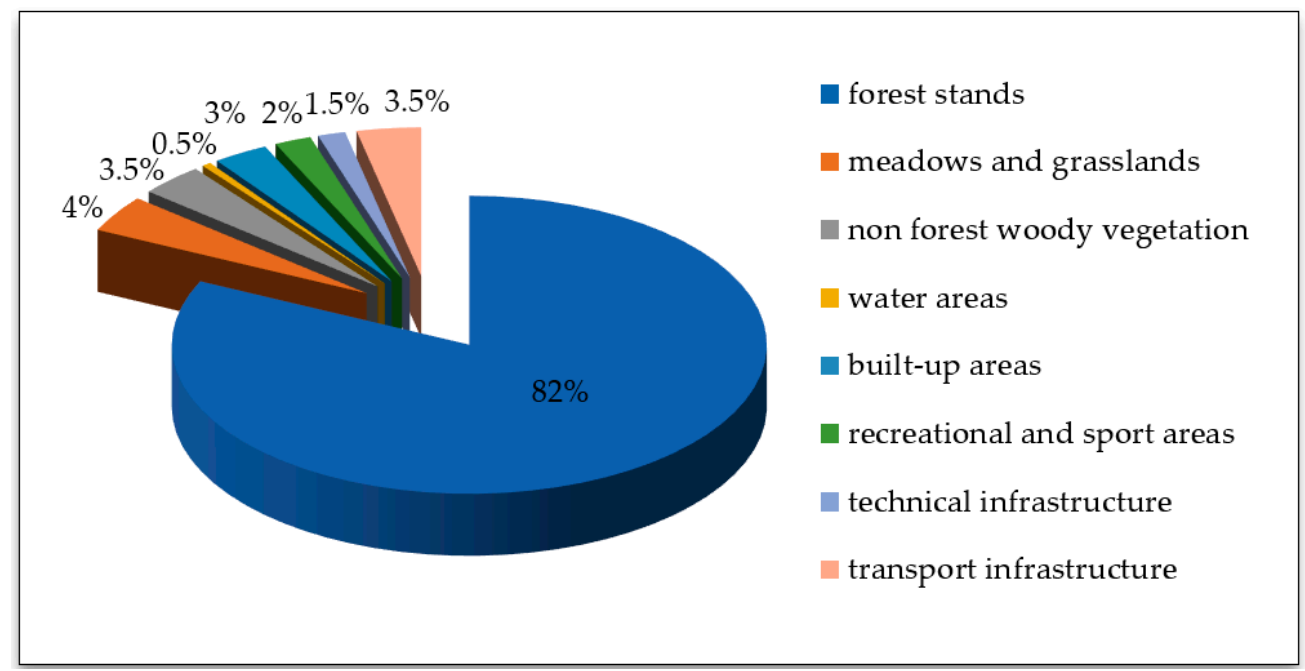

Figure 4. The representation of the main landscape structure elements in the model area.

The current state of landscape structure elements is most significantly negatively affected by the movement and activity of tourists and vacationers in the locality (direct reduction in surface water quality, destruction of current vegetation cover, disturbance of local fauna, spread of non-native invasive species, etc.), forest management activities (uncontrolled tree felling and the state of forest stands care) and changes in microclimatic conditions due to the changing climate (direct damage to forest stands by snow phenomena, icing, strong winds, changes in species composition, etc.).

The ecological significance of landscape elements also depends on their ecological stability. In the area, ecologically stable elements were identified (forest stands, water elements, extensively managed meadows, etc., presented in Figure 5) and ecologically unstable elements (anthropogenically created elements of technical character, especially transport lines, transport areas, built-up areas, etc.). Based on the comparison of their spatial and relative representation, the model area was evaluated as an ecologically stable landscape. The final evaluation is based mainly on the high proportion of forest stands in the locality and other natural and nature-friendly elements, but in terms of further evaluation, it is necessary to take into account the gradual increase in negative impacts on the current state of these elements and their declining quality, due to an increasing number of visitors.

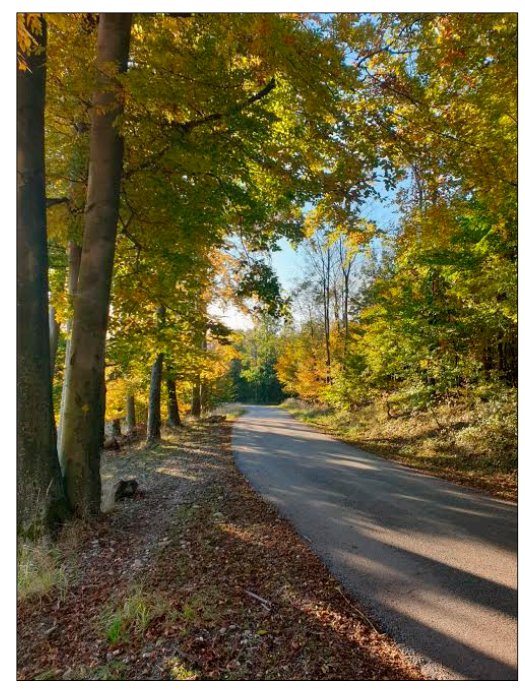

Figure 5. Interior of the city forest park in Bratislava. 
Based on the collected data on individual receptors, we determined the sensitivity of their evaluation criteria (SE) and their significance $(S I)$ in terms of maintaining the required quality of the landscape. The choice of receptors and individual assessment criteria was based on the model set presented in this paper, but the resulting set of criteria was based on knowledge of the abiotic and biotic conditions of the site and was adapted to the purpose of the research. For each criterion, the data collection methods used were also taken into account by evaluating the confidence intervals (IS), where it is true that the lower the value of the confidence interval, the more reliable the data that the resulting evaluation is based on. The results are summarized in Table 4.

Table 4. Values of vulnerability indicators of assessment criteria of the model area of Železná studnička.

\begin{tabular}{ccccc}
\hline Receptor & Assessment Criteria & $S E$ & $S I$ & IS \\
\hline \multirow{3}{*}{ Natural values } & Forest stands and non-forest woody vegetation & 4 & 45 & 0.3 \\
& Watercourses and areas & 3 & 35 & 0.5 \\
\multirow{3}{*}{ Protected areas } & Biota & 3 & 20 & 0.3 \\
& Areas and elements protected by law & 2 & 30 & 0.3 \\
& Natura 2000 Sites & 3 & 35 & 0.5 \\
Landscape structure & Biotopes of European and national importance & 4 & 35 & 0.5 \\
\hline \multirow{2}{*}{ Landscape image } & Landscape elements & 3 & 50 & 0.1 \\
& Land use & 2 & 50 & 0.1 \\
\hline \multirow{2}{*}{ Ecological significance } & Visual character of the landscape & 2 & 50 & 0.1 \\
& Architectural trends & 2 & 50 & 0.1 \\
\hline \multirow{3}{*}{ Cultural and historical values } & Current state of landscape elements & 4 & 60 & 0.1 \\
& Ecological stability of the landscape & 4 & 40 & 0.3 \\
\hline \multirow{2}{*}{ Tourist and recreational } & Cultural sites and events & 2 & 50 & 0.5 \\
infrastructure & Historical sites & 3 & 30 & 0.1 \\
& Local traditions and values & 1 & 20 & 0.7 \\
\hline & Recreation facilities & 3 & 40 & 0.1 \\
& Sporting sites & 3 & 35 & 0.1 \\
Transport infrastructure & Tourist attractions & 4 & 25 & 0.1 \\
\hline & Site connectivity & 2 & 20 & 0.3 \\
& Access roads & 2 & 35 & 0.1 \\
& Tourist trails & 3 & 15 & 0.1 \\
& Bicycle paths & 3 & 15 & 0.1 \\
& Nature trails & 4 & 15 & 0.1 \\
\hline
\end{tabular}

$\overline{S E \text { : sensitivity (1 very low sensitivity }-5 \text { very high sensitivity), SI: significance (\%), IS: confidence interval }}$ (1 expert assessment, $0.7,0.5,0.3,0.1$ specific survey).

Based on the recalculation of the obtained partial values in accordance with the presented methodological procedure, the degree of vulnerability of individual receptors was determined $(V)$. The obtained values are given in Table 5 , together with the resulting value of the degree of reliability of the assessment performed $(R)$.

Table 5. Values of the degree of receptor vulnerability and the degree of reliability of the assessment.

\begin{tabular}{ccc}
\hline Receptor & $\boldsymbol{V}$ & $\boldsymbol{R}$ \\
\hline Natural values & 3.45 & 0.730 \\
Protected areas & 3.05 & 1.021 \\
Landscape structure & 2.05 & 0.227 \\
Landscape image & 2.00 & 0.141 \\
Ecological significance & 4.00 & 0.268 \\
Cultural and historical values & 2.10 & 0.994 \\
Tourist and recreational infrastructure & 3.25 & 0.257 \\
Transport infrastructure & 2.45 & 0.552
\end{tabular}

$V$ : receptor vulnerability (1 very low vulnerability-5 very high vulnerability), $R$ : assessment reliability (the higher the value, the lower the accuracy of the assessment).

As can be seen from the table above, the most vulnerable receptor in the model area is the ecological significance of landscape elements (vulnerability value 4). The resulting 
value takes into account the gradually declining quality of the landscape elements of the model area and several identified activities with negative or potentially negative effects on these elements (inappropriate forest management, reducing forest areas at the expense of building access roads and recreational facilities and areas, interventions in riparian vegetation of the Vydrica watercourse, etc.). The fact that the currently still high ecological stability of the area is rather the result of a high proportion of natural and nature-friendly elements (especially forest stands) was also respected, while as a result of implemented and considered activities, intensification of recreation and sports opportunities in the locality, and the rising pressure of the visitors, the condition and quality of landscape elements is considerably endangered.

The vulnerability of natural values of the model area was evaluated as medium (vulnerability value 3.45). The locality is mostly covered by forest stands (they make up more than $82 \%$ of its area), which are, however, also its main attraction in terms of traffic. The vulnerability of natural elements thus increases in proportion to their sensitivity and significance for the site and, at the same time, is based on many identified negative factors to which they have recently been exposed (especially direct destruction and gradual degradation of biotopes by inappropriate management, presence of visitors, and direct interventions due to the increasing demands for recreational and sports areas).

The medium vulnerability was also assessed for the tourist and recreational infrastructure receptor (vulnerability value 3.25). In the model area, which is mainly part of the zone of intensive recreation of the Železná Studnička site, there are currently rich opportunities for tourist, recreational, and sports activities, including accommodation and food facilities, outdoor seating, gazebos, fireplaces, playgrounds, and specific sports facilities, climbing areas, ski resorts, bobsled tracks, cycling and hiking trails, etc. The resulting vulnerability of these elements is based mainly on increasing traffic to this site, not only by residents of the capital, but also by residents of surrounding municipalities, increasing pressure on these elements by intensifying their use and increasing demands of visitors for the diversity and number of recreational opportunities and their quality.

Medium vulnerability was also assessed for the receptor of protected areas (vulnerability value 3.05), which are represented in the model area by the protected landscape area of the Little Carpathians, the area of European importance, Vydrica, and the presence of several rare forest and non-forest biotopes, including wetlands. The resulting value of the vulnerability of this receptor is mainly based on increasing urban pressures at the southern edge of the model locality, where the effort to expand the urban background of Bratislava towards a locality close to nature is monitored, as well as direct interventions in biotopes due to the increasing demands on recreational and sports sites.

The vulnerability of other monitored landscape receptors (landscape structure, landscape image, cultural and historical values of the area, transport infrastructure) was evaluated as low, i.e., there is no presumption of them being significantly negatively affected by the current or planned use of the recreational site. The obtained values are based on the relatively constant relative representation of landscape elements in the area, low sensitivity of the landscape image from a broader point of view for the presence of forest stands, absence of specific historical or cultural elements, sufficient number of access roads, and good internal interconnection of the model area.

The identified degree of reliability of the vulnerability assessment of each monitored receptor indicates in more detail the reliability and accuracy of the assessment performed. The higher the value of the resulting degree of reliability, the less accurate methods were used in its investigation, and the lower the objectivity and reality of the obtained result. As shown in Table 5, the highest values of reliability were achieved in this case for the receptors of protected areas and local cultural and historical values, the evaluation of which was based on data taken from available surveys and studies from different time periods processed on different bases. On the contrary, the most accurate and reliable assessment was made for the receptors landscape image, landscape structure, tourist and recreational 
infrastructure, and ecological significance of landscape elements, which was based on a detailed field survey of the model site, i.e., based on primary, current data.

The obtained values of vulnerability of individual receptors express their current state and their susceptibility to undesirable changes, therefore they can be used as threshold limits for determining future land use. As the landscape vulnerability evaluation can help with the identification of the most vulnerable localities within a particular landscape and with the determining of the most suitable human activities there, it can be an important part of site management when considering its further recreational use, i.e., designing a suitable model of tourism. Moreover, the knowledge of the reliability of the whole evaluation enables proper reflection of the reality and leads to the better proposals for future model of tourism.

\section{Discussion}

The landscape is a highly heterogeneous system which, if it is set up as a research object, requires the collection and processing of large amounts of data. The necessary data can be obtained by conducting detailed surveys that allow the identification and knowledge of all its individual parts, as well as comprehensive research methods to understand their interrelationships and ongoing processes [40]. Even though complex landscape ecological research techniques have been developed, they are usually difficult to implement, require a high level of expertise with knowledge from several scientific disciplines, and are time consuming [15]. These are major obstacles to their integration into the other methodological procedures.

This paper presents a proposal of a specific landscape-ecological method for examining the landscape in its comprehensive way and identifying its thresholds by assessing its vulnerability to external influences. This method is designed with regard to determining the sustainable and environmentally friendly model of tourism. As stated in [14], vulnerability assessment is a key approach of landscape optimization, based on environmental planning and management, as it enables consideration of environmental requirements in an integrated and transparent way, by considering the needs and proposals for its future development. It is therefore recommended as a base for defining management measures and criteria, regulations, and guidelines for land use.

As the inner differentiation is the main objective of landscape unit, its discontinuity is manifested by its structuring into specific units-the relatively homogenous segments [41]. The presented LVA method reflects this phenomenon as it is based on determining the partial vulnerability of individual landscape elements (landscape receptors). Structuring landscape into specific receptors enables its comprehensive understanding.

As indicated in [42], even though advances have been made in the research of landscape up to now, the functional links between patterns and processes are often still poorly understood. Therefore, greater effort needs to be expended in understanding the functional aspects of landscapes. This issue can be fulfilled through the comprehensive landscape analysis that is an important initial part of the landscape vulnerability assessment. Landscape vulnerability, as one of the landscape attributes, considers the landscape in its holistic character [43]. It represents the capacity of natural components and their processes to provide materials and services for social function [44]. In addition, it includes not just the individual characteristics of its receptors, but it reflects their mutual functional relationships as well.

The analytical part of the LVA method consists of the evaluation of landscape receptors using the specific criteria that enables us to understand their structure, composition, and present state. These criteria are further evaluated using two basic parameterstheir sensitivity to external influences and their significance for the receptor as a unit. The selected sequence allows for the broader consideration of different environmental aspects of a research area. The obtained partial values are finally converted to the overall degree of vulnerability of each receptor; the synthetic part of the procedure involves the mutual confrontation of these parameters and also the interpretation of their mutual corre- 
lation. As described in [45], in order to provide the adequate level of services, it is necessary to maintain the "sufficient" state of the landscape receptors which allows these services. A precondition for maintaining such a state is an understanding of the processes that take place in the landscape and by which the landscape is created. This method saturates this issue with evaluation performed in a presented way, as it not just represents detailed analysis of the examined area, but also expresses its resistance to the effects of external influences. In addition, thanks to the partial outputs, the method allows us to work with the obtained information flexibly, according to the focus of the research.

As with other landscape ecological methods, the presented LVA method maintains a certain degree of subjectivity by incorporating a qualitative assessment of landscape receptors. This is mainly due to the subject of research itself, which is highly differentiated, as it contains many incoherent components with complex interrelationships [46]. Moreover, several efforts have been recorded in landscape ecology and landscape planning to identify evaluation uncertainties resulting from the diverse character of the landscape [47]. The presented LVA method reflects the variability of the used sub-methods by incorporating the parameter of assessment reliability. The knowledge of the level of the subjectivity of the whole evaluation thus helps interpret the obtained results more accurately.

To increase the objectivity of the final evaluation, the LVA method also incorporates a quantitative dimension consisting of the use of criteria analysis and subsequent processing of partial results. The values of criterion sensitivity, criterion significance, and resulting receptor vulnerability denote an attempt to standardize the procedure, which makes the results clearer for further interpretation, their mutual comparison, and their following use. These steps also contribute to increasing the application of the results and to their general acceptance, which is not a rare problem in landscape ecological assessments [48].

Other advantages of the proposed LVA method include the relative simplicity of its processing and low financial demands, as the implementation of specific additional surveys is not always a necessity [43]. The advantage of the procedure is also its wider applicability, as the method was developed as a broad-spectrum landscape ecological procedure, allowing its adaptation to specific research needs: in the analytical phase it is possible to adapt the list of environmental receptors, as well as the use of other monitored parameters. The method can thus be more easily integrated into various landscape ecological procedures and can also be applied in other areas of landscape management, such as determining recreational potential $[49,50]$ or evaluating recreational ecosystem services [51].

As with other procedures, the presented method has also certain limitations. As mentioned before, the particular degree of subjectivity is still maintained here, and although the level of the reliability is incorporated to indicate its extent, it is only an assumption because the input variables are not directly measurable. However, it at least indicates the extent of the inaccuracy and allows the evaluator to denote the potential questions. Another difficult issue is the need for precise data about the landscape receptors, because the accuracy of the criteria analysis depends on sufficient data. A further issue is connected to its application, this method should be conducted by an expert with extensive experience in landscape research as it requires comprehensive knowledge of receptors functions, their evaluation, and the interpretation of results. Moreover, there is a future possibility to better reflect the mutual relationships of landscape receptors. All of the limitations listed here represent typical issues of methods used in landscape ecology as they mainly resulted from the complex structure of the landscape as a research objective.

The basic pros of the method are of a great importance for its further use in the field of recreation and tourism research, as it is based on a detailed knowledge of the landscape and its limits for its possible future use, while maintaining its quality [52]. The landscape vulnerability analysis designed in this way not only enables knowledge of the actual state of abiotic, biotic, and socio-economic landscape elements and their specifics, but also evaluates their susceptibility to undesirable changes [33]. It creates a possibility to set a strategy for landscape management adequately, while confirming the 
importance of the use of landscape ecological research in setting strategies for sustainable land use for tourism [53]. However, the landscape vulnerability analysis also helps select appropriate forms of tourism that not only underline the natural, cultural, and socioeconomic conditions of the area, but also do not create an excessive burden and contribute to maintaining its required quality.

\section{Conclusions}

As the tourism industry brings massive anthropogenic influences on the landscape affected, for preserving its required quality and maintaining the ongoing human interests, it is important to know the local limitations. This paper outlines the specific method for assessing the vulnerability of the landscape by examining its actual state and defining its thresholds for determining an environmentally friendly model of tourism.

The presented method enables us to fully understand the local landscape, its specificities, and also its limits. It is based on the qualitative and quantitative assessment of the individual landscape receptors using the specific criteria and indicators that denote their detailed characterization, the understanding of their present status, and also their limitations. These are implied by determining the degree of vulnerability of each landscape receptor as an attribute that reflects the ability of the receptor to sustain the external influences without any disruption or destruction. Integrated criteria evaluation increases the objectivity of the entire assessment process and enables the inclusion of a larger range of experts to improve its informative value. Simultaneously, maintaining a certain degree of subjectivity of the evaluation process makes it possible to adapt the method to the specific requirements of the society. The generated outcomes and their interpretation represent an important database for determining sustainable land use of the area. As the results can interpret the local limitations for the ongoing development, the method is well designed to help suggest the sustainable tourism management.

Author Contributions: M.V., K.P., Z.K. article writing; M.V., K.P., Z.K. performed the literature review, M.V., Z.K. map creation; Z.K., M.V., K.P. research idea, article writing, and formatting; they jointly contributed to the structure and aims of the manuscript. All authors have read and agreed to the published version of the manuscript.

Funding: This research was funded by the Scientific Grant Agency at the Ministry of Education of the Slovak Republic and Slovak Academy of Sciences as part of the VEGA project no. 2/0077/21 "Integration of supply of selected ecosystem services for societal demand in terms of developing sustainable forms of tourism". The APC was funded by Faculty of Natural Sciences, Comenius University in Bratislava.

Institutional Review Board Statement: Not applicable.

Informed Consent Statement: Not applicable.

Data Availability Statement: All relevant data are within the paper.

Acknowledgments: The authors would like to thank the Scientific Grant Agency at the Ministry of Education of the Slovak Republic and Slovak Academy of Sciences.

Conflicts of Interest: The authors declare no conflict of interest.

\section{References}

1. Oueslati, W.; Salanit, E. Landscape Valuation and Planning. J. Environ. Policy Plan. 2011, 54, 1-6. [CrossRef]

2. Wu, J. Landscape Ecology, Cross-Disciplinarity, and Sustainable Science. Landsc. Ecol. 2006, 21, 1-4. [CrossRef]

3. Grzywacz, R.; Žegleń, P. Principles of Tourism and Recreation; Wydawnictwo Uniwersytetu Rzeszowskiego Rzeszów: Rzeszów, Poland, 2014; 95p.

4. Pavličková, K.; Vyskupová, M.; Igondová, E. Rajecká Dolina recreational landscape potential. J. Land. Manag. 2014, 5, 21-27.

5. Sunlu, U. Environmental impacts of tourism. In Local Resources and Global Trades: Environments and Agriculture in the Mediterranean Region; Camarda, D., Grassini, L., Eds.; CIHEAM Options Méditerranéennes: Paris, France, 2003; pp. $263-270$.

6. Harris, R.; Griffin, T.; Williams, P. Sustainable Tourism: A Global Perspective; Routledge: Oxford, UK, 2002; 311p.

7. Ravencroft, D. The environmental impact of recreation and tourism development: A review. Environ. Policy Gov. 1992, 2, 8-13. 
8. Anděl, J.; Balej, M.; Jeřábek, M.; Oršulák, T.; Raška, P. Comprehensive Geographical Research of the Cultural Landscape: II. Part Development of Environmental Stress in Northwestern Bohemia in the Period of Transformation; Komplexní geografický výzkum kulturní krajiny: II. díl Vývoj environmentálního stresu v severozápadních Čechách v období transformace; MINO: Ústí nad Labem, Czech Republic, 2008; 176p.

9. $\mathrm{Wu}, \mathrm{J}$. Key concepts and research topics in landscape ecology revisited: 30 years after the Allerton Park workshop. Landsc. Ecol. 2013, 28, 1-11. [CrossRef]

10. Forman, T.T.R.; Godron, M. Landscape Ecology; Krajinná Ekologie; Academia: Prague, Czech Republic, 1993; 583p.

11. Varšavová, M. Vulnerability assessment of the abiotic complex of the alpine environment of the Belianske Tatras. Hodnotenie zranitel'nosti abiotického komplexu vysokohorského prostredia Belianskych Tatier. Oecol. Mont. 2002, 11, 19-23.

12. Lindhjem, H.; Reinvang, R.; Zandersen, M. Landscape Experiences as a Cultural Ecosystem Service in a Nordic Context: Concepts, Values and Decision-Making; Rosendahls-Schultz Grafisk: Copenhagen, Denmark, 2015; 189p.

13. Mlakar, A. Relevance of vulnerability analysis and environmental premises for comprehensive planning. Geod. Vestn. 2009, 53, 526-542.

14. Golobič, M.; Žaucer, B. Landscape Planning and Vulnerability Assessment in the Mediterranean—Final Report; Regional Activity Center for the Priority Actions Program: Ljubljana, Slovenia, 2010; 92p.

15. Vyskupová, M. Landscape evaluation methods within EIA in Slovakia. In Proceedings of the International Academic Symposium Planned and Normative Protection of Space and Environment, Palić, Subotica, Serbia, 4-6 April 2013; The Association of Spatial Planners of Serbia: Belgrade, Serbia; pp. 35-41.

16. Minár, J. Geoecological (complex physical-geographical) research and mapping on a large scale. Geoekologický (komplexný fyzickogeografický)výskum a mapovanie vo vel'kých mierkach. Geogr. Spectr. 2001, 3, 1-210.

17. Toro, J.; Duarte, O.; Requena, I.; Zamorano, M. Determining vulnerability importance in environmental impact assessment The case of Colombia. Environ. Impact Assess. Rev. 2012, 32, 107-117. [CrossRef]

18. Eakin, H.; Luers, L. Assessing the vulnerability of social-environmental systems. Annu. Rev. Environ. Resour. 2006, 31, 365-394. [CrossRef]

19. Tran, L.T.; Knight, C.G.; O’Neil, R.V.; Smith, E.R.; Ritters, K.H.; Wickham, J. Fuzzy decision analysis for integrated environmental vulnerability assessment of the mid-Atlantic Region. Environ. Manag. 2002, 29, 845-859. [CrossRef] [PubMed]

20. Toro, J.; Requena, I.; Duarte, O.; Zamorano, M. A qualitative method proposal to improve environmental impact assessment. Environ. Impact Assess. Rev. 2013, 43, 9-20. [CrossRef]

21. Luers, A.; Lobella, D.; Sklard, L.; Addamsa, L.; Matsona, M. A method for quantifying vulnerability applied to the agricultural system of the Yaqui Valley Mexico. Glob. Environ. Chang. 2003, 13, 255-267. [CrossRef]

22. Li, A.; Wang, A.; Liang, S.; Zhuoa, W. Eco-environmental vulnerability evaluation in mountainous region using remote sensing and GIS-A case study in the Upper Reaches of Minjiang River, China. Ecol. Model. 2006, 192, 175-187. [CrossRef]

23. Drdoš, J.; Mocik, A.; Ondrášik, R.; Soták, Š.; Vrana, K.; Bedrna, Z.; Kibíček, F.; Ružičková, H.; Kalivodová, E.; Hrnčiarová, T.; et al. Methodological Manual to the Act. of the National Council of the Slovak Republic No. 127/1994 Coll. on Environmental Impact Assessment, Part Ecological Carrying Capacity; MoE SR: Bratislava, Slovakia, 1996; 49p.

24. Wilson, K.; Pressey, R.; Newton, A.; Burgman, M.; Possingham, H.; Weston, C.H. Measuring and incorporating vulnerability into conservation planning. Environ. Manag. 2005, 35, 527-543. [CrossRef]

25. Janessen, R. On the use of multi-criteria analysis in Environmental impact assessment in the Netherlands. J. Multi-Criteria Decis. Anal. 2001, 10, 101-109. [CrossRef]

26. Dodgson, J.S. Multi-Criteria Analysis: A Manual; Communities and Local Government Publications: London, UK, 2009; 168p.

27. Ružička, M.; Miklós, L. Landscape-ecological planning (LANDEP) in the process of the territorial planning. Ecology 1982, 1, 297-312.

28. Hrnčiarová, T.; Miklós, L.; Kalivodová, E.; Kubíček, F.; Ružičková, H.; Izakovičová, Z.; Drdiš, J.; Rosová, V.; Kovačevičová, S.; Midriak, R.; et al. Ecological Bearing Capacity of the Landscape: Methodology and Application to 3 Beneficial Areas; Ekologická únosnost' krajiny: Metodika a aplikácia na 3 benefičné územia. Part I.-IV. Ecological project; MoE SR, ILE SAS, GEF: Bratislava, Slovakia, 1997; 490p.

29. Bastian, O.; Krönhert, R.; Lipský, Z. Landscape diagnosis on different space and time scales-A challenge for landscape planning. Landsc. Ecol. 2006, 21, 359-374. [CrossRef]

30. Muradyan, V.S.; Asmaryan, S.G. Applying landscape-ecological concept and GIS modelling for assessing and mapping of ecological situation of mountainous landscapes (on the case of Syunik marz, Armenia). Geocarto Int. 2015, 30, 1077-1091. [CrossRef]

31. Pavličková, K.; Vyskupová, M. A method proposal for cumulative environmental impact assessment based on the landscape vulnerability evaluation. Environ. Impact Assess. Rev. 2015, 50, 74-84. [CrossRef]

32. Huang, I.B.; Keisler, J.; Linkov, I. Multi-criteria decision analysis in environmental sciences: Ten years of applications and trends. Sci. Total Environ. 2011, 409, 3578-3594. [CrossRef] [PubMed]

33. Vyskupová, M.; Pavličková, K.; Baus, P. A landscape vulnerability analysis method proposal and its integration in EIA. J. Environ. Plann. Man. 2017, 60, 1193-1213. [CrossRef]

34. Frederik, J. Statistical Methods in Experimental Physics; World Scientific Publishing: London, UK, 2006; 364p. 
35. Markechová, D.; Tirpáková, M.; Stehlíková, B. Basics of Statistics for Teachers; Základy štatistiky pre pedagógov. FNS; Constantine the Philosopher University in Nitra: Nitra, Slovakia, 2011; 405p.

36. Bock, R.K.; Grote, H.; Notz, D.; Regler, M.; Früwirth, R. Data Analysis Techniques for High Energy Physics Experiments; Cambridge University Press: Cambridge, UK, 2000; 448p.

37. Freedman, D.A. Statistical Models: Theory and Practice; Cambridge University Press: Cambridge, UK, 2009; 458p.

38. Benyovszky, K. Železná Studnička; Marenčin PT: Bratislava, Slovakia, 2005; 96p.

39. Loft, A.S. Evaluation of the Traffic Survey; Vyhodnotenie Prieskumu Návštevnosti: Bratislava, Slovakia, 2012; 28p.

40. Turner, M.G.; Gardner, R.H.; O’Neil, R.V. Landscape Ecology in Theory and Practice: Pattern and Process; Springer: New York, NY, USA, 2003; 403p.

41. Kolejka, J. The Landscape Theory. The Geographical Insight and Scope; Náuka o Krajine-Geografický Pohled a Východiska; Academia Praha: Prague, Czech Republic, 2013; 439p.

42. Hobbs, R. Future landscapes and the future of landscape ecology. Landsc. Urban. Plan. 1997, 37, 1-9. [CrossRef]

43. Vyskupová, M. Methodical Procedures for the Evaluation of Landscape Attributes in Environmental Impact Assessment; Metodické Postupy Hodnotenia Atribútov Krajiny v Posudzovaní Vplyvov na Životné Prostredie. Ph.D. Thesis, Faculty of Natural Sciences, Comenius University in Bratislava, Bratislava, Slovakia, 2015.

44. De Groot, R.S. Functions of Nature: Evaluation of Nature in Environmental Planning, Management and Decision Making; WoltersNoordhoff Gronigen: Wageningen, The Netherlands, 1992; 315p.

45. Moldan, B. Captured Planet; Podmaněná planeta; Karolinum: Prague, Czech Republic, 2009; 420p.

46. Van Der Heide, M.; Heijman, W. The Economic Value of Landscapes; Routledge: London, UK, 2013; 336p.

47. Neuendorf, F.; von Haaren, C.; Albert, C. Assessing and coping with uncertainties in landscape planning: An overview. Landsc. Ecol. 2018, 33, 861-878. [CrossRef]

48. Klopatek, J.M.; Gardner, R.H. (Eds.) Landscape Ecological Analysis-Issues and Applications; Springer: New York, NY, USA, 1999; 400p.

49. Dudek, T. Recreational potential as an indicator of accessibility control in protected mountain forest areas. J. Mt. Sci. 2017, 14, 1419-1427. [CrossRef]

50. Cetic, M.; Sevik, H.; Canturk, U.; Cakir, C. Evaluation of the recreational potential of Kutahya urban forest. Fresenius Environ. Bull. 2017, 27, 2629-2634.

51. Hermes, J.; van Berkel, D.; Burkhard, B.; Plieninger, T.; Fagerholm, N.; von Haaren, C.; Albert, C. Assessment and evaluation of recreational ecosystem services of landscapes. Ecosyst. Serv. 2018, 31, 289-295. [CrossRef] [PubMed]

52. Ivlev, V.; Ivleva, M.; Panyukov, A.; Zulfugarzade, T. Analysis of the Touristic Recreational Potential of a Territory as a Condition for Development of Ecological Tourism (the Southern Moscow Region Case Study). J. Environ. Manag. Tour. 2017, 2, $373-384$.

53. Aranzabal, I.; Schmitz, M.; Pineda, F. Integrating Landscape Analysis and Planning: A Multi-Scale Approach for Oriented Management of Tourist Recreation. Environ. Manag. 2009, 44, 938-951. [CrossRef] [PubMed] 